UDK 577.1 : 61

ISSN 1452-8258

J Med Biochem 41: 156-161, 2022

Original paper

Originalni naučni rad

\title{
INCREASED MATERNAL LEPTIN LEVELS MAY BE AN INDICATOR OF SUBCLINICAL HYPOTHYROIDISM IN A NEWBORN
}

\author{
POVEĆANI NIVO MAJČINSKOG LEPTINA MOŽE BITI POKAZATELJ \\ SUBKLINIČKOG HIPOTIROIDIZMA KOD NOVOROĐENČADI
}

\author{
Hande Karpuzoglu1, Yasemin Ucal' ${ }^{1}$, Pinar Kumru' ${ }^{2}$, Murat Muhcu ${ }^{3}$, Mustafa Eroglu4, \\ Muhittin Serdar ${ }^{1}$, Mustafa Serteser ${ }^{1}$, Aysel Ozpinar ${ }^{1}$ \\ ${ }^{1}$ Department of Medical Biochemistry, School of Medicine, Acibadem Mehmet Ali Aydinlar University, Istanbul, Turkey \\ 'Zeynep Kamil Research and Training Hospital, Department of Obstetrics and Gynecology, Istanbul, Turkey \\ ${ }^{3}$ Umraniye Training and Research Hospital, Department of Obstetrics and Gynecology, Istanbul, Turkey \\ ${ }^{4}$ Haydarpasa Numune Training and Research Hospital, Department of Obstetrics and Gynecology, Istanbul, Turkey
}

\section{Summary}

Background: Several factors may influence newborn thyroid-stimulating hormone (TSH) concentrations and cause subclinical hypothyroidism in a newborn. A sufficient level of leptin signalling is needed for the normal production of TSH and thyroid hormones by the thyroid gland. Our study aimed to investigate the correlation between maternal serum leptin concentration during the third trimester of pregnancy and newborn screening-TSH levels.

Methods: This prospective cross-sectional study was conducted in obstetrics and gynaecology clinics of a state hospital between June and August 2013. Maternal venous blood samples were collected from 270 healthy pregnant women in the third trimester just before delivery. Measurements of maternal fT3, fT4, TSH, anti-thyroid peroxidase (TPO), and anti-thyroglobulin (anti-Tg) antibodies from serum samples were performed by chemiluminescence immunoassay. Maternal serum leptin levels were determined by ELISA. Dried capillary blood spots were used to measure newborn TSH levels.

Results: Subjects were divided into two groups according to the neonatal TSH levels using a cut-point of $5.5 \mathrm{mIU} / \mathrm{L}$. Median maternal serum leptin levels were significantly higher in newborns whose TSH levels were higher than $>5.5 \mathrm{mlU} / \mathrm{L}[13.2 \mu \mathrm{g} / \mathrm{L}(1.3-46.5)$ vs $19.7 \mu \mathrm{g} / \mathrm{L}(2.4-$ 48.5), $\mathrm{p}<0.05]$. Serum leptin levels showed a negative

\section{Kratak sadržaj}

Uvod: Postoji nekoliko faktora koji mogu uticati na koncentraciju tiroidno-stimulišućeg hormona (TSH) kod novorođenčadi i na izazivanje subkliničkog hipotiroidizma. Da bi štitna žlezda normalno proizvodila TSH i tiroidne hormone potreban je dovoljan nivo signalizacije leptina. $U$ našoj studiji smo želeli da istražimo korelaciju između koncentracije serumskog majčinskog leptina tokom trećeg trimestra trudnoće i nivo TSH na skriningu kod novorođenčadi.

Metode: Ova prospektivna studija preseka sprovedena je na akušersko-ginekološkim klinikama jedne državne bolnice u periodu od juna do avgusta 2013. Uzorci venske krvi majki prikupljeni su od 270 zdravih trudnica u trećem tromesečju neposredno pre porođaja. Merenje majčinskih fT3, fT4, TSH, antitireoidnih peroksidaza (TPO) i antitireoglobulinskih (anti-Tg) antitela iz serumskih uzoraka izvedeno je hemiluminiscentnim imunološkim testom. Nivo leptina u serumu kod majki je određen ELISA testom. Za merenje nivoa TSH kod novorođenčadi korišćene su suve kapilarne krvne tačke.

Rezultati: Ispitanici su podeljeni u dve grupe prema neonatalnim nivoima $\mathrm{TSH}$ sa graničnom vrednošću od 5,5 $\mathrm{mIU} / \mathrm{L}$. Srednji nivo serumskog leptina je bio značajno veći kod novorođenčadi čiji su nivoi TSH bili veći od $>5,5$ $\mathrm{mIU} / \mathrm{L}[13,2 \mu \mathrm{g} / \mathrm{L}(1,3-46,5)$ naspram 19,7 $\mu \mathrm{g} / \mathrm{L}(2,4-$ $48,5), p<0,05]$. Nivo leptina u serumu je pokazao nega-

\footnotetext{
Address for correspondence:

Aysel Ozpinar

Department of Biochemistry, Acibadem University Kerem Aydinlar Campus, Istanbul, 34752, Turkey Phone: +90216500 4060, +905435323142 Fax: +902165765076 e-mail: aysel.ozpinar@acibadem.edu.tr
} 
correlation with maternal fT4 $(r=0.32, p<0.05)$, fT3 $(r=0.23, p<0.05)$, and a positive correlation with BMI $(r=0.30, p<0.05)$.

Conclusions: Our results suggest that high leptin levels in the third trimester of pregnancy influence maternal thyroid functions and might cause an increase in newborn TSH levels. Detection of high maternal serum leptin levels may be a reason for subclinical hypothyroidism.

Keywords: leptin, congenital hypothyroidism, maternalfetal relations, newborn TSH (Thyroid Stimulating Hormone), maternal thyroid hormones

\section{Introduction}

Adipose tissue is an active endocrine organ that secretes various bioactive hormones called adipokines with multiple metabolic, neuroendocrine, cardiovascular, and inflammatory functions (1). Leptin is a hormone that is exclusively secreted by adipose tissue and encoded by the ob gene. The primary role of leptin is to regulate energy homeostasis and suppress food intake, thereby inducing weight loss (2). In addition, leptin has a vital role in the regulation and synthesis of thyroid hormones. In the paraventricular nucleus of the hypothalamus, leptin has a regulatory role in the expression and secretion of thyrotropinreleasing hormone (TRH); thus, it has a regulatory effect on thyroid-stimulating hormone (TSH) and thyroid hormone production (3).

One of the most common preventable causes of mental retardation among newborns is congenital hypothyroidism $(\mathrm{CH})$. It is possible to diagnose newborn $\mathrm{CH}$ at early stages with newborn $\mathrm{CH}$ screening programs. Agenesis or dysgenesis of the thyroid gland and thyroid hormone production deficiency are the most common causes of permanent $\mathrm{CH}$ (4). However, several other factors may influence newborn TSH concentrations and cause mild hypothyroidism. lodine deficiency, maternal hypothyroidism (5), maternal medications, blocking antibodies (6), body mass index (BMI), and smoking (7), as well as weight gain during pregnancy (8), are well-known factors that may affect newborn thyroid function. A number of physiological and hormonal changes occur in pregnant women, such as changes in leptin concentrations. Increasing adipose tissue stores and secretion from the placenta results in elevated concentrations of leptin (9), which peaks at the end of the second or beginning of the third trimester and remains stable after that until delivery (10). Leptin was suggested to play the primary role as a regulator of fetal growth and development (11).

The mechanisms of how leptin influences newborn thyroid function are not known. This study investigated the correlation between screening TSH levels in the newborn and serum leptin concentration of the mother at the third trimester to test whether increased leptin levels affect newborn thyroid function. tivnu korelaciju sa majčinim fT4 $(r=0,32, p<0,05)$, fT3 $(r=0,23, p<0,05)$ i pozitivnu korelaciju sa BMI $(r=0,30$ $\mathrm{p}<0,05)$.

Zaključak: Naši rezultati ukazuju da visoki nivoi leptina u trećem tromesečju trudnoće utiču na funkcije štitne žlezde majke i mogu izazvati i povećati nivo TSH kod novorođenčadi. Otkrivanje visokog nivoa majčinskog leptina u serumu može biti razlog za subklinički hipotiroidizam.

Ključne reči: leptin, urođeni hipotiroidizam, odnosi majke i fetusa, TSH (hormon za stimulaciju štitne žlezde) novorođenčeta, hormoni štitne žlezde majke

\section{Patients and Methods}

\section{Patients}

A total of three hundred healthy full-term pregnant women (37-41 weeks of gestational age) were included in this prospective cross-sectional study. This study did not include pregnant women with multiple gestations, abnormal ultrasound findings, and metabolic diseases. In addition, 30 out of 300 participants were excluded due to missing data $(n=6)$, premature births ( $<37$ weeks) $(n=10)$, and thyroid hormone abnormalities during pregnancy $(n=14)$. All infants were born by spontaneous delivery $(n=270)$. There was no evidence of fetal distress during labour.

\section{Sample Collection and Laboratory Measurements}

Maternal venous fasting blood (8 hours fasting) samples were collected in the $38^{\text {th }}$ week of pregnancy in the morning and were kept at $-80^{\circ} \mathrm{C}$ until analyses. Free T4 (fT4), free T3 (fT3), TSH, anti-thyroglobulin (anti-Tg) antibody, and anti-thyroid peroxidase (TPO) antibody measurements were made using chemiluminescence immunoassay (CLIA) with Advia Chemistry XPT System (Siemens Diagnostics, Germany). Enzyme-linked immunosorbent assay (ELISA) was used to measure leptin levels (DIA source Europe SA; Nivelles, Belgium). Inter-assay coefficient variation for fT4, fT3, TSH, anti-Tg antibody, and anti-TPO antibody at low levels were 1.21, 2.35, 2.28, 9.06, and $6.43 \%$, and at high levels were $4.55,1.61,2.71$, 8.14 , and 1.74 , respectively.

Heel-prick samples of whole blood were collected on filter paper cards from all newborns within 3 to 5 days after delivery. Dried capillary blood spots were used for TSH measurements.

\section{Statistical Analysis}

Participants were divided into two groups according to newborn TSH levels using a cut-off value of $5.5 \mathrm{mlU} / \mathrm{L}$ based on the definitions of the Turkish national newborn screening program for congenital hypothyroidism (12): group 1: TSH $5.5 \mathrm{mlU} / \mathrm{L}$, 
group 2: TSH >5.5 mIU/L. Leptin levels and hormone concentrations showed a non-normal distribution; therefore, they are expressed as median and first and third quartiles, and intergroup comparisons were made using the Mann-Whitney U test. Pearson's correlation analysis was used to examine the correlation between newborn TSH and maternal leptin levels. Spearman's test was used to examine the correlations between leptin concentrations, thyroid hormones, and other clinical parameters in mothers. A p-value of $<0.05$ was considered statistically significant.

\section{Results}

According to newborn TSH levels, Table I compares demographical characteristics such as gestational and maternal age, body mass index, birth weight, and intrapartum laboratory findings. Gestational age, maternal age, body mass index, and birth weight were similar across the two groups $(p>0.05)$. In addition, the groups showed similar findings for TSH, fT4, anti-TG, anti-TPO levels ( $p>0.05)$. On the other hand, maternal leptin levels were significantly higher [13.2 (1.3-46.5) vs 19.7 (2.4-48.5) $\mu \mathrm{g} / \mathrm{L}, \mathrm{p}<0.05]$ and $\mathrm{fT} 3$ levels were signif-

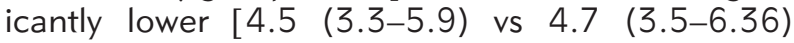

Table I Demographic and laboratory characteristics of the studied population according to the newborn TSH levels. Maternal and newborn characteristics were compared with the newborn using a TSH cut-point of $5.5 \mathrm{mIU} / \mathrm{L}$.

\begin{tabular}{|c|c|c|c|c|c|}
\hline \multicolumn{6}{|l|}{ Newborn TSH (mIU/L) } \\
\hline & \multicolumn{2}{|c|}{$\begin{array}{l}\text { Group I } \mathrm{n}=140 \\
\text { TSH } 5.5(\mathrm{mlU} / \mathrm{L})\end{array}$} & \multicolumn{2}{|c|}{$\begin{array}{c}\text { Group II } \mathrm{n}=130 \\
>5.5(\mathrm{mIU} / \mathrm{L})\end{array}$} & \multirow[b]{2}{*}{ p-value } \\
\hline & Median & $2.5-97.5 \mathrm{P}$ & Median & $2.5-97.5 \mathrm{P}$ & \\
\hline Maternal age & 26 & $19-40$ & 26 & $18.9-37.2$ & $p>0.05$ \\
\hline Pregnancy period & 38 & $35-42$ & 40 & $32-42$ & $p>0.05$ \\
\hline $\mathrm{BMI}$ & 28.5 & $21.1-38.2$ & 28.4 & $21.2-39.2$ & $p>0.05$ \\
\hline Intrapartum TSH (mIU/L) & 2.2 & $0.59-8.65$ & 2.3 & $0.6-6.1$ & $p>0.05$ \\
\hline Intrapartum FT4 (pmol/L) & 11.9 & $8.31-16.63$ & 11.7 & $8.7-16.2$ & $p>0.05$ \\
\hline Intrapartum FT3 (pmol/L) & 4.7 & $3.5-6.36$ & 4.5 & $3.3-5.9$ & $\mathrm{p}^{*}<0.05$ \\
\hline Intrapartum anti TG (kIU/L) & 15.8 & $10-122.6$ & 26.8 & $10-86.2$ & $p>0.05$ \\
\hline Intrapartum anti TPO (kIU/L) & 5.6 & $5-110$ & 5.9 & $5-71.6$ & $p>0.05$ \\
\hline Intrapartum Leptin $(\mu \mathrm{g} / \mathrm{L})$ & 13.2 & $1.3-46.5$ & 19.7 & $2.4-48.5$ & $\mathrm{p}^{*}<0.05$ \\
\hline Baby Weight (gram) & 3360 & $2042-4253$ & 3280 & $2647-3923$ & $p>0.05$ \\
\hline
\end{tabular}

Data arepresented as median, first and third interquertile ranges (IQR).

$\mathrm{p}<0.05$; Statistical significance of the difference between group I and II.

Table II Spearman's $\rho$ coefficients of correlations between maternal serum leptin levels and other parameters.

\begin{tabular}{|c|c|c|}
\hline & Correlation ( $r$ ) & $p$-value \\
\hline Maternal age & -0.2 & $>0.05$ \\
\hline Pregnancy period & 0.014 & $>0.05$ \\
\hline \multicolumn{3}{|l|}{ Intrapartum } \\
\hline BMI & 0.30 & $<0.001$ \\
\hline $\mathrm{TSH}(\mathrm{mlU} / \mathrm{L})$ & -0.03 & $>0.05$ \\
\hline fT4 (pmol/L) & -0.32 & $<0.001$ \\
\hline fT3 (pmol/L) & -0.23 & $<0.05$ \\
\hline Anti-TG (kIU/L) & -0.049 & $>0.05$ \\
\hline Anti-TPO (kIU/L) & -0.077 & $>0.05$ \\
\hline \multicolumn{3}{|l|}{ Newborn } \\
\hline Weight $(\mathrm{kg})$ & 0.049 & $>0.05$ \\
\hline TSH (mIU/L) & 0.16 & $<0.05$ \\
\hline
\end{tabular}

Bolded values indicate statistical significance.

leptın as a novel placenta-derıved hormone in humans

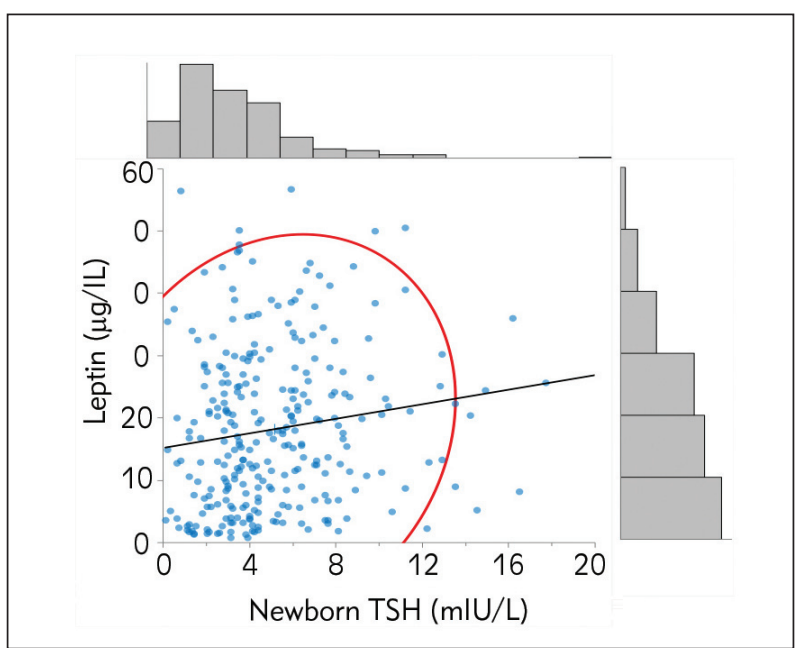

Figure 1 Correlation between maternal leptin and newborn TSH levels. Pearson's correlation coefficient was determined as $0.16(p<0.05)$. The frequency histogram shows the number of values $(n)$ in the corresponding axis. The red curve represents $95 \% \mathrm{Cl}$ of the distribution. 


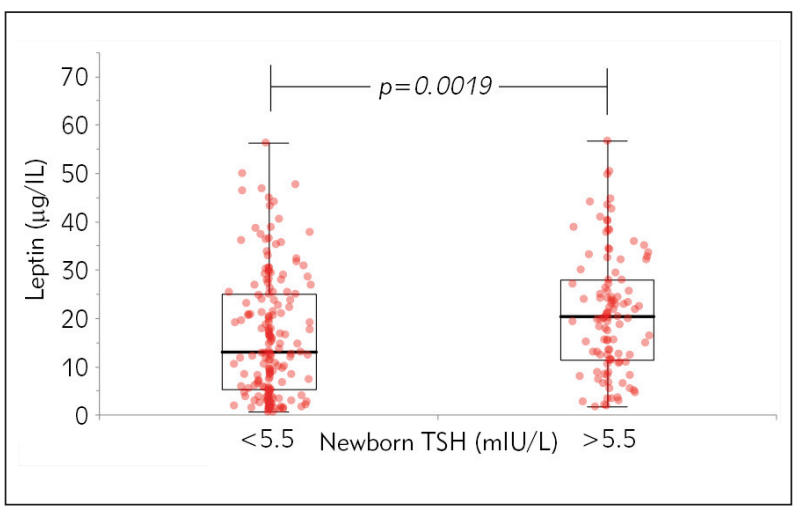

Figure 2 Relationship between newborn TSH and maternal serum leptin levels. $\mathrm{p}<0.05$ was considered as a significant difference.

$\mathrm{pmol} / \mathrm{L}, \mathrm{p}<0.05$ ] in group 2 when compared to group 1 (Table I).

Correlations with leptin levels and other parameters are shown in Table II. Serum leptin levels had negative correlations with intrapartum fT4, fT3, and positive correlations with BMI and newborn TSH levels. Figure 1 demonstrates the positive correlation between maternal serum leptin concentrations and newborn TSH levels $(r=0.16, p<0.05)$.

\section{Discussion}

This study examined the relations between maternal serum leptin and thyroid hormone levels in the third trimester and TSH levels of the newborn measured from capillary blood samples and found a positive correlation between newborn TSH levels and maternal leptin levels. This is the first study to focus on the relation between third-trimester maternal serum leptin levels and the thyroid function of the newborn.

T3 and T4 circulating in the fetus are of maternal origin during the first trimester; whereas, developing the fetal thyroid gland increasingly contributes to the levels of the thyroid hormones from the beginning of the second trimester. Thyroid hormones have crucial roles in healthy fetal growth and development (13). Several environmental factors may affect the thyroid function of the mother and the newborn (14). lodine deficiency (15), maternal thyroid hormones (5), low birth weight infants (16), pregnancy duration, maternal weight gain during pregnancy (8), high $\mathrm{BMI}$, and lifetime smoking behaviour (7) are among the known factors associated with subclinical hypothyroidism in the newborn. One of the well-established causes of subclinical hypothyroidism during infancy is iodine deficiency; such that world Health Organization (WHO) recommended the use of a percentage of newborns with a TSH $>5 \mathrm{mlU} / \mathrm{L}$ as a marker for population iodine deficiency (17). The
Turkish Newborn Screening Program recommends spot TSH levels of $5.5 \mathrm{mlU} / \mathrm{L}$ as a threshold for detecting congenital hypothyroidism $(12,15)$. In our study, leptin levels were significantly higher in mothers of newborns whose TSH levels were higher than $>5.5 \mathrm{mlU} / \mathrm{L}$. Our results showed that increased maternal leptin levels could influence newborn TSH levels, which can be one of the main reasons for subclinical hypothyroidism in the newborn.

Leptin has modulatory roles in critical processes such as invasion, proliferation, protein synthesis, and placental cell apoptosis during early pregnancy (18). In the later stages of a healthy pregnancy, increasing nutrient availability and regulating fetal growth is required. However, elevated leptin concentrations may represent a state of leptin resistance, which may be due to reduced bioactivity or reduced sensitivity at the hypothalamic level (19). On the other hand, leptin overproduction by the placenta is associated with diabetes mellitus (20), hypertension (21), high BMI (7), and weight gain during pregnancy $(8,22)$. Diabetes, obesity, and inflammation seem to be associated with the development of peripheral leptin resistance, which causes impaired leptin signalling in the brain (19). Therefore, it is crucial to understand both the physiological and pathological effects of increased leptin levels during pregnancy on the mother and the newborn. In the present study, thirdtrimester leptin levels were positively correlated with $\mathrm{BMI}$ and maternal weight. These results are consistent with the findings of Sattar et al. (23), who found a positive correlation between $\mathrm{BMI}$ and third-trimester leptin levels. An increase in leptin levels is expected during pregnancy due to fat tissue accumulation (23).

Additionally, Shaarawy et al. (24) reported a positive correlation between weight gain and $\mathrm{BMI}$ as well as third-trimester leptin levels in pregnant women. However, in contrast with our findings, they did not find a significant difference between pregnant women with high and normal BMI in terms of leptin levels. The results of that study supported the suggestion that leptin release is mainly placenta-based during pregnancy (25).

Increased weight gain during pregnancy results in higher fetal weight gain (26). Although leptin levels are known to increase with increasing fat tissue, we were not able to find a correlation between maternal leptin levels and the birthweight of the newborn. Similarly, Serapio et al. (27) found no correlation between maternal leptin levels and weight at birth. However, Manderson et al. (28) found an association between birth weight and cord leptin levels. On the other hand, Stefaniak et al. (29) found an association between birth weight and cord leptin levels $(r=0.23$; $p=0.00$ ), but not between the birthweight and maternal leptin levels. These studies support that cord leptin may increase fetal adipose tissue. 
Various factors such as autoimmunity, fertility, hormones like estrogen, gender, insulin resistance, and high $\mathrm{BMI}$ affect the relationship between thyroid function and leptin (30). The relation between leptin levels and thyroid function were examined in many studies. In our study, we found inverse relations between fT4/fT3 and leptin levels measured in the third trimester. However, we could not find correlations between maternal TSH hormone levels, levels of anti-TG and TPO, and leptin hormone. Pop et al. (22) recently examined the adverse effects of high BMI during pregnancy on thyroid function. In that study, pregnant women who gained much weight were found to have higher TSH levels and lower FT4 levels than pregnant women with a healthy weight increase. Their study speculated that the excessive leptin released from fat tissue might have affected the thyroid function of pregnant women (22). Our results are in line with that study.

In the study by lacobellis et al. (31), a positive correlation was found between TSH and leptin levels adjusted for BMI in euthyroid obese women $(r=0.33$ $p=0.03$ ). On the contrary, Betry et al. (32) showed a positive association between leptin and TSH levels independent of BMI in healthy individuals $(p<0.001)$. Several studies showed conflicting results; some researchers showed a negative correlation, whereas others could not show a significant modulatory role for leptin on thyroid function (30).

In our study, the median leptin level was 19 $\mu \mathrm{g} / \mathrm{L}$ (IQR: 1.546) in the third trimester, which was similar to the distribution of leptin levels in the study by Okdemir et al. (33). In the cited study, the median leptin level was $7.32 \mu \mathrm{g} / \mathrm{L}$ (range, 1.00-33.19) and $12.54 \mu \mathrm{g} / \mathrm{L}$ (range, 1.07-45.75) in pregnant women with healthy and excess weight gain, respectively. On the other hand, Mazaki-Yovi's research found higher leptin levels at the third trimester: $30.2 \mu \mathrm{g} / \mathrm{L}$ (range, 16.9-43.5) (34). These suggest that BMI and weight gain, as well as ethnicity, may affect leptin levels.

To the best of our knowledge, this is the first study revealing that maternal leptin levels may be correlated with maternal thyroid functions and increased newborn TSH levels and subclinical hypothyroidism. This study was limited in such a way that it was a cross-sectional study in which maternal blood was obtained only in the third trimester, and pregnancies

\section{References}

1. Coelho M, Oliveira T, Fernandes R. Biochemistry of adipose tissue: An endocrine organ. Arch Med Sci 2013; 9: 191-200.

2. Friedman JM. Leptin and the endocrine control of energy balance. Nat Metab. Springer US; 2019; 1.

3. Mantzoros CS. Leptin and the hypothalamus: Neuroendocrine regulation of food intake. Mol Psychiatry 1999; 4: 8-12. were not regularly followed up. Larger prospective studies are warranted to elucidate the clinical relevance of our findings, focusing on the maternal thyroid functions, leptin levels, and weight gain during the first and second trimesters.

Funding. No funding sources available.

Contributors. Aysel Ozpinar was the Principal Investigator of the study and contributed to the design of the research, data interpretation, and supported manuscript writing. Hande Karpuzoglu wrote the manuscript. Hande Karpuzoglu and Yasemin Ucal contributed to data analysis and interpretation. Pinar Kumru, Murat Muhcu, and Mustafa Eroglu were involved in subject selection and sample collection at the hospital. Muhittin Serdar contributed to the lab analysis and statistical analysis. Mustafa Serteser helped supervise the project. All authors drafted the manuscript, critically revised the manuscript, and agreed to be fully accountable for ensuring the integrity and accuracy of the work.

Ethical approval. The study protocol was approved by the Acibadem University Ethics Committee (ATADEK 2013-507), and the study was conducted following the Declaration of Helsinki and its later amendments. All subjects gave informed consent before enrolment into the study.

Consent to participate. All participants received informed consent, and a signed copy was filed.

Consent for publication. All authors read and approved the final manuscript.

Data availability. The data that support the findings of this study are available from the corresponding author upon reasonable request.

Data deposition. The data will not be deposited.

Geolocation information. Not available.

Supplemental online material. Not available.

Health and safety. Not available.

\section{Conflict of interest statement}

All the authors declare that they have no conflict of interest in this work.

4. Rose S.R ATA. Update of newborn screening and therapy for congenital hypothyroidism. Off J Am Acad Pediatrıcs 2006; 2290-303.

5. Blazer S, Moreh-Waterman Y, Miller-Lotan R, Tamir A, Hochberg Z. Maternal Hypothyroidism May Affect Fetal Growth and Neonatal Thyroid Function 2003; 102: 232-41.

6. Trumpff C, Vandevijvere S, Moreno-Reyes R, Vanderpas J, Tafforeau J, Oyen H Van, et al. Neonatal thyroid-stim- 
ulating hormone level is influenced by neonatal, maternal, and pregnancy factors. Nutr Res. Elsevier Inc.; 2015; 35 (11): 975-81.

7. Filis $P$, Hombach-Klonisch S, Ayotte $P$, Nagrath N, Soffientini U, Klonisch $\mathrm{T}$, et al. Maternal smoking and high BMI disrupt thyroid gland development. BMC Medicine; 2018; 1-15.

8. Kahr MK, Antony KM, Delbeccaro M, Hu M, Aagaard KM, Suter MA. Increasing maternal obesity is associated with alterations in both maternal and neonatal thyroid hormone levels. Clin Endocrinol (Oxf) 2016; 84(4): 551-7.

9. Mouzon SH, Lepercq J, Catalano P. The known and unknown of leptin in pregnancy. Am J Obstet Gynecol 2006.

10. Dağdeviren M, Akkan T, Yapar D, Karakaya S, Dağdeviren T, Ertuğrul D, Altay M. Can neutrophil/lymphocyte ratio be used as an indicator of inflammation in patients with hyperthyroidism? J Med Biochem 2020; 39 (1): 7-12.

11. Schanton $M$, Maymó JL, Pérez-pérez A, Sánchez-margalet V, Varone CL. Placenta, 2015.

12. Donbaloğlu Z, Savaş-Erdeve Ş, Çetinkaya S, Aycan Z. Cases referred from the Turkish national screening program: Frequency of congenital hypothyroidism and etiological distribution. JCRPE J Clin Res Pediatr Endocrinol 2019; 11: 240-6.

13. Bernal J. Thyroid hormone receptors in brain development. Nat Clin Pract Endocrinol Metab 2007; 3 (3): 249-59.

14. Morreale de Escobar G, Obregon MJ, Escobar del Rey F. Fetal and maternal thyroid hormones. Horm Res 1987; 26: 12-27.

15. Çaylan N, Tezel B, Özbaş S, Şahin N, Aydın Ş, Acıcan D, et al. Neonatal thyroid-stimulating hormone screening as a monitoring tool for iodine deficiency in Turkey. JCRPE J Clin Res Pediatr Endocrinol 2016; 8: 187-91.

16. Ng SM, Wong SC, Paize F, Chakkarapani E, Newland P, Didi M. Multivariate analyses of factors that affect neonatal screening thyroid stimulating hormone. J Pediatr Endocrinol Metab 2011; 24(9-10): 727-32.

17. Assessment of iodine deficiency disorders and monitoring their elimination. 3rd edition. Geneva: WHO; 2007.

18. Antonio P, Maym J, Fern M. Leptin action in normal and pathological pregnancies. Leptin mediates the crosstalk between adipose tissue and reproduction. Role of leptin in placenta development. J Cell Mol Med 2018; 22: 716-27.

19. Barrenetxe J. Leptin resistance and diet-induced obesity: central and peripheral actions of leptin. Metabolism 2015; 64 (1): 35-46.

20. Vitoratos N, Salamalekis E, Kassanos D, Loghis C, Panayotopoulos N, Kouskouni E, et al. Maternal plasma leptin levels and their relationship to insulin and glucose in gestational-onset diabetes. Gynecol Obstet Invest 2001; 51: 17-21.

21. Taylor BD, Ness RB, Olsen J, Hougaard DM, Skogstrand
K, Roberts JM, et al. Preeclampsia Serum Leptin Measured in Early Pregnancy Is Higher in Women With Preeclampsia Compared With Normotensive Pregnant Women. Hypertension 2014; 594-9.

22. Pop VJ, Biondi B, Wijnen HA, Kuppens SM, Vader HL. Maternal thyroid parameters, body mass index and subsequent weight gain during pregnancy in healthy euthyroid women. Clin Endocrinol (Oxf) 2013; 577-83.

23. Sattar N, Greer I, Pirwani I, Gibson J, Michael A, Sattar $N$, et al. Leptin levels in pregnancy, marker for fat accumulation and mobilization? Leptin levels in pregnancy: marker for fat accumulation and mobilization? Acta Obstet Gynecol Scand 2017; 6349.

24. Shaarawy M, El-Mallah SY. Leptin and gestational weight gain: Relation of maternal and cord blood leptin to birth weight. J Soc Gynecol Investig 1999; 6: 70-3.

25. Sagawa N, Itoh H, Matsumoto T, Mise H, Liu W, Nuamah $M A$, et al. Leptın as a novel placenta-derıved hormone in humans -A Review-. Placenta, Volume 20, Supplement 1, 1999; 25-34.

26. Monte S, Valenti O, Giorgio E, Renda E, Hyseni E, Faraci $M$, et al. Maternal weight gain during pregnancy and neonatal birth weight: a review of the literature. J Prenat Med 2011; 5: 27-30.

27. Serapio S, Ahlsson F, Larsson A, Kunovac Kallak T. Second Trimester Maternal Leptin Levels Are Associated with Body Mass Index and Gestational Weight Gain but not Birth Weight of the Infant. Horm Res Paediatr 2020; 92: 106-14.

28. Manderson JG, Patterson CC, Hadden DR, Traub Al, Leslie $\mathrm{H}, \mathrm{McC}$ ance DR. Leptin concentrations in maternal serum and cord blood in diabetic and nondiabetic pregnancy. Am J Obstet Gynecol 2003; 188: 1326-32.

29. Stefaniak M, Dmoch-Gajzlerska E, Mazurkiewicz B, Gajzlerska-Majewska W. Maternal serum and cord blood leptin concentrations at delivery. PLoS One 2019; 14: 1-12.

30. Zimmermann-Belsing T, Brabant G, Holst JJ, FeldtRasmussen U. Circulating leptin and thyroid dysfunction. Eur J Endocrinol 2003; 149(4): 257-71.

31. lacobellis G, Ribaudo MC, Zappaterreno A, lannucci CV, Leonetti F. Relationship of thyroid function with body mass index, leptin, insulin sensitivity and adiponectin in euthyroid obese women. Clin Endocrinol (Oxf) 2005; 62: 487-91.

32. Bétry C, Challan-Belval MA, Bernard A, Charrié A, Drai J, Laville $M$, et al. Increased TSH in obesity: Evidence for a BMI-independent association with leptin. Diabetes Metab. Elsevier Masson SAS; 2015; 41: 248-51.

33. Ökdemir D, Hatipo lu N, Kurto lu S, Siraz ÜG, Akar HH, Muhtaro lu S, et al. The Role of Irisin, Insulin and Leptin in Maternal and Fetal Interaction. J Clin Res Pediatr Endocrinol 2018; 10: 307-15.

34. Mazaki-Tovi S, Kanety H, Pariente C, Hemi R, Wiser A, Schiff $E$, et al. Maternal serum adiponectin levels during human pregnancy. J Perinatol 2007; 27: 77-81. 